\title{
Increased dietary availability of selenium in rainbow trout (Oncorhynchus mykiss) improves its plasma antioxidant capacity and resistance to infection with Piscirickettsia salmonis
}

Javiera Pérez-Valenzuela ${ }^{1,2+}$, Madelaine Mejías ${ }^{1,2+}$, Daniela Ortiz ${ }^{1,2,3}$, Pablo Salgado ${ }^{1,2,3}$, Liliana Montt ${ }^{1,2}$, Ignacio Chávez-Báez ${ }^{1,2}$, Francisca Vera-Tamargo ${ }^{1,2}$, Dinka Mandakovic ${ }^{1,2,4}$, Jurij Wacyk ${ }^{2,3^{*}}$ and Rodrigo Pulgar ${ }^{1,2^{*}}$ (i)

\begin{abstract}
Salmonid Rickettsial Septicaemia (SRS), caused by Piscirickettsia salmonis, is the most important infectious disease in the Chilean salmon farming industry. An opportunity to control this disease is to use functional micronutrients to modulate host mechanisms of response to the infection. Since P. salmonis may affect the host antioxidant system in salmonids, particularly that dependent on selenium (Se), we hypothesized that fish's dietary selenium supplementation could improve the response to the bacterial infection. To address this, we defined a non-antibiotic, non-cytotoxic concentration of selenium to evaluate its effect on the response to in vitro infections of SHK-1 cells with P. salmonis. The results indicated that selenium supplementation reduced the cytopathic effect, intracellular bacterial load, and cellular mortality of SHK-1 by increasing the abundance and activity of host glutathione peroxidase. We then prepared diets supplemented with selenium up to 1,5, and $10 \mathrm{mg} / \mathrm{kg}$ to feed juvenile trout for 8 weeks. At the end of this feeding period, we obtained their blood plasma and evaluated its ability to protect SHK-1 cells from infection with P. salmonis in ex vivo assays. These results recapitulated the observed ability of selenium to protect against infection with P. salmonis by increasing the concentration of selenium and the antioxidant capacity in fish's plasma. To the best of our knowledge, this is the first report of the protective capacity of selenium against $P$. salmonis infection in salmonids, becoming a potential effective host-directed dietary therapy for SRS and other infectious diseases in animals at a non-antibiotic concentration.
\end{abstract}

Keywords: Piscirickettsia salmonis, Selenium, Diet, Salmonid, Infection, Host-directed therapy

\footnotetext{
*Correspondence: jwacyk@uchile.cl; rpulgar@uchile.cl

${ }^{\dagger} J a v i e r a$ Pérez-Valenzuela and Madelaine Mejías contributed equally to this work

${ }^{1}$ Laboratorio de Genómica y Genética de Interacciones Biológicas

(LG2IB), Instituto de Nutrición y Tecnología de los Alimento, Universidad de Chile, El Líbano, Macul, 5524 Santiago, Chile

${ }^{2}$ Center for Research and Innovation in Aquaculture (CRIA), Universidad de Chile, Santiago, Santiago, Chile

Full list of author information is available at the end of the article
}

\section{Introduction}

Aquaculture is the third-largest productive sector in Chile, where the main species produced and exported are salmonids like Atlantic salmon (Salmo salar), Pacific salmon (Oncorhynchus kisutch), and Rainbow trout (Oncorhynchus mykiss). These species generated 1.6 billion dollars in 2019 only by the concept of exportation [1]. However, the industry has faced an increase

(c) The Author(s) 2021. This article is licensed under a Creative Commons Attribution 4.0 International License, which permits use, sharing, adaptation, distribution and reproduction in any medium or format, as long as you give appropriate credit to the original author(s) and the source, provide a link to the Creative Commons licence, and indicate if changes were made. The images or other third party material in this article are included in the article's Creative Commons licence, unless indicated otherwise in a credit line to the material. If material is not included in the article's Creative Commons licence and your intended use is not permitted by statutory regulation or exceeds the permitted use, you will need to obtain permission directly from the copyright holder. To view a copy of this licence, visit http://creativeco mmons.org/licenses/by/4.0/. The Creative Commons Public Domain Dedication waiver (http://creativecommons.org/publicdomain/ zero/1.0/) applies to the data made available in this article, unless otherwise stated in a credit line to the data. 
in economic losses due to infectious diseases, among which Piscirickettsiosis or Salmon Rickettsial Septicemia (SRS) stands out. SRS has prevailed for more than 30 years without effective control and generating millionaire losses of around 450 million dollars per year, reaching the point of being considered a "chronic" problem for the sector [2]. This disease is caused by the bacterium Piscirickettsia salmonis, which can infect, replicate, and propagate in host cells' intracellular vacuoles, its main cytopathic effect (CPE) [3].

Prophylactic strategies like vaccines used to fight SRS have been unsuccessful, so antibiotics are the most used approach. It has been described that more than $80 \%$ of the total antibiotics used in the Chilean salmon industry are against SRS since the doses tend to be higher than those administered to other bacterial diseases given the intracellular facultative nature of $P$. salmonis [4]. This strategy and the emergence of bacterial strains resistant to these antibiotics have severely impacted the country's image, and the sustainability of the industry has been strongly questioned because of this [5]. Hence, new strategies not harmful to the fish or their environment are required to address this pathology.

A novel therapeutic strategy is host-directed therapy (HDT), which is based on the use of micronutrients and/ or drugs that modulate host mechanisms essential for pathogen replication or persistence, therefore improving the host defense against the pathogen [6]. However, the challenge is to identify the cellular mechanisms relevant to fight the infection and then establish the micronutrients or drugs that disrupt those mechanisms.

Studies addressing salmonids' transcriptional response to infection with $P$. salmonis suggest that the bacterium may affect the host antioxidant system, eventually causing cell death and necrosis in several fish tissues with SRS. In particular, Rise et al. in 2004 [7] described the regulation of genes involved in response to oxidative stress in head kidney and macrophages of Atlantic salmon infected with P. salmonis. Interestingly, the most highly up- and down-regulated antioxidants in $P$. salmonis infected macrophages (glutathione peroxidase and selenoprotein $\mathrm{P}$, respectively) are functionally dependent on selenium. This observation has also been described by other authors that studied the response of other salmonids' tissues to the infection with this bacterium [8-10]. Therefore, these studies suggest that the antioxidant host response, particularly dependent on selenium, could be relevant to fight $P$. salmonis infection.

Selenium is an essential micronutrient linked to various biological functions such as the antioxidant and anti-inflammatory response, the thyroid gland's activity, fertility, and the response to infection [11]. Interestingly, seleno-deficient areas in China produce a human endemic cardiomyopathy (Keshan syndrome) attributed to the coxsackievirus B3 (CVB3), which mainly affects children and young people. The prevention of this disease is achieved with selenium supplementation in the diet from an early age [12]. Also, the supranutritional supplementation of selenium-yeast resulted in suppressing the progression of the HIV-1 viral load and the increase in CD4 + T cells in HIV-1 patients when their serum selenium increased significantly [13].

In fish, selenium deficiency has also been shown to correlate with increased mortality in channel catfish exposed to the intracellular bacterium Edwardsiella ictaluri [14]. Also, chinook salmon infected with Renibacterium salmoninarum significantly increased their mortality when fed with selenium-deficient diets compared to standard selenium concentration control diets [15]. These results suggest that selenium availability is relevant for an adequate response to intracellular pathogens.

Currently, Chilean salmon aquaculture uses organic selenium in the form of selenium-yeast to supplement the diets. Juvenile salmonids are being fed in a $1 \mathrm{mg} \mathrm{Se} /$ $\mathrm{Kg}$ concentration, representing the minimum concentration required to avoid a deficit in growth [16]. Since higher selenium supplementation levels $(3.5-4.3 \mathrm{mg} / \mathrm{Kg}$ ) have been shown to improve growth performance and antioxidant capacity of fish [17], we investigated if selenium supplementation at non-antibiotic nor-toxic concentrations has a protective capacity against $P$. salmonis in salmon macrophages infected in vitro and ex vivo. This investigation gives the first insights into a potential effective host-directed therapy based on supplementing a micronutrient in the diet of salmonids infected with $P$. salmonis, which could become a complementary dietary strategy to other therapeutic approaches to combat SRS.

\section{Materials and methods}

\section{SHK-1 and bacterial culture conditions}

The SHK-1 cell line (ECACC 97111106) was obtained from the European Collection of Authenticated Cell Cultures (ECACC). Cells were cultivated at $18{ }^{\circ} \mathrm{C}$ in Leibovitz L-15 medium (Gibco, USA) supplemented with $5 \%$ of inactivated fetal bovine serum (FBS, Gibco) and $0.1 \mu \mathrm{M}$ of 2-mercaptoethanol (Sigma-Aldrich, Germany) in T-75 flasks (Corning, USA). Piscirickettsia salmonis LF-89 (ATTC VR-1361) used in this study was obtained from the American Type Culture Collection (ATCC) and was cultivated at $18{ }^{\circ} \mathrm{C}$ in solid and liquid SRS-broth media [18] with a constant $180 \mathrm{rpm}$ stirring. Each subculture was confirmed as $P$. salmonis by Gram staining and RFLP assay [19]. For sodium selenite $\left(\mathrm{Na}_{2} \mathrm{SeO}_{3}\right.$, Sigma-Aldrich) treatment, SHK-1 cells were seeded and cultured with Leibovitz L-15 medium supplemented with $5 \%$ of FBS (Gibco) without antibiotics in 24-well plates 
(Corning). Twenty-four hours later, cells approximately $80 \%$ confluent were supplemented with different concentrations $(0 ; 0.5 ; 1.0 ; 1.5 ; 2.0 ; 10$ and $100 \mu \mathrm{M})$ of $\mathrm{Na}_{2} \mathrm{SeO}_{3}$ to evaluate their viability by the trypan blue exclusion assay in Neubauer chambers [20]. In parallel, P. salmonis LF-89 was sub-cultured at $18{ }^{\circ} \mathrm{C}$ with an initial optical density $\left(\mathrm{OD}_{620}\right)$ of 0.05 in SRS-broth media and supplemented with different concentrations of $\mathrm{Na}_{2} \mathrm{SeO}_{3}(0 ; 1.0$; $2.0 ; 4.0 ; 6.0 ; 8.0$ and $10 \mu \mathrm{M})$. To assess viability, the bacterial growth was measured by absorbance using the spectrophotometer Infinite ${ }^{\circledR} 200$ PRO NanoQuant (Tecan Technologies, Switzerland). The viability of SHK-1 and $P$. salmonis was measured in ten biological replicates in at least two independent experiments for 12 days.

\section{Relative abundance and activity of glutathione peroxidase (Gpx1) in SHK-1}

To evaluate the effect of a non-cytotoxic concentration of sodium selenite on the selenoprotein glutathione peroxidase (Gpx1), we compared the transcripts abundance and activity of Gpx1 between non-supplemented and supplemented SHK-1 cells with $1 \mu \mathrm{M}$ of $\mathrm{Na}_{2} \mathrm{SeO}_{3}$ for $24 \mathrm{~h}$. Briefly, the total RNA of $1 \times 10^{6} \mathrm{SHK}-1$ cells was isolated by EZNA Total RNA kit I (OMEGA Bio-tek, USA) and quantified using a Qubit Fluorometric Quantitation System (Life Technologies, USA). According to standard procedures, we used $2 \mu \mathrm{g}$ of total RNA as a template for reverse transcription reactions to synthesize cDNA using All-In-One 5X RT MasterMix (Amb, Canada). PCR was carried out on a real-time PCR System (Roche, Switzerland) using Brilliant II SYBR Green kit (Agilent Technologies, USA), and PCR conditions were $95{ }^{\circ} \mathrm{C}$ for $5 \mathrm{~min}$ followed by $94{ }^{\circ} \mathrm{C}$ for $15 \mathrm{~s}, 60^{\circ} \mathrm{C}$ for $15 \mathrm{~s}$ and $72{ }^{\circ} \mathrm{C}$ for $20 \mathrm{~s}$ for a total of 35 cycles, using primers for glutathione peroxidase 1-like (XM_014133872.1) (F_gpx1: 5'-GGATGT GAATGGGAAGGATG-3'; R_gpx1: 5'-AGCGCTTGT AAGGATCTCCA-3') and for elongation factor 1-alpha (XM_014177562.1) (F_ef-1a: 5'-CACCACCGGCAA TCTGATCTACAA-3'; R_ef-1a: 5'-TCAGCAGCCTCC TTCTCGAACTTC- $3^{\prime}$ ), which was selected as a normalizer gene. At least three technical replicates were performed for each quantification. To determine the activity of (Gpx1), we used the Paglia and Valentine method [21] with some modifications. Briefly, $1 \times 10^{6} \mathrm{SHK}-1$ cells were lysed before enzyme assays by sonication three times for $5 \mathrm{~s}$ on Branson Digital Sonifier (SFX 550, Emerson, USA), followed by centrifugation at $3500 \mathrm{rpm}$, for $10 \mathrm{~min}$ at $4{ }^{\circ} \mathrm{C}$ to remove the debris. The lysate was resuspended with the reaction mixture and incubated for $4 \mathrm{~min}$ at $18{ }^{\circ} \mathrm{C}$. After this, tert-butyl hydroperoxide was added to achieve final concentrations of $50 \mathrm{mM}$ potassium phosphate buffer (pH 7.6), $0.63 \mathrm{mM}$ reduced glutathione, $0.25 \mathrm{mM}$
NADPH, $5 \mathrm{mM}$ EDTA, $5 \mu \mathrm{g} / \mathrm{mL}$ Glutathione reductase and $0.1 \mathrm{mM}$ tert-butyl hydroperoxide. After $1 \mathrm{~min}$, the absorbance at $340 \mathrm{~nm}$ was measured for $4 \mathrm{~min}$ at $18{ }^{\circ} \mathrm{C}$ on the spectrophotometer Infinite ${ }^{\circledR} 200$ PRO NanoQuant (Tecan Technologies). The enzyme activity (U), defined as one mole of NADPH oxidized per minute, was normalized with the total protein concentration measured using the Bradford method. The results of 32 measures in at least two independent experiments were expressed as a percentage of activity at $24 \mathrm{~h}$ with respect to the activity in the basal culture conditions, without supplementation with selenium.

\section{In vitro infection assay}

In vitro infections of SHK-1 cells with $P$. salmonis were performed according to Caruffo et al. [22]. Briefly, $1 \times 10^{3}$ SHK-1 cells were seeded on coverslips and cultured with Leibovitz's L-15 medium supplemented with 5\% of FBS (Gibco) without antibiotics in 24 wells plates (Corning). Twenty-four hours later, cells approximately $80 \%$ confluent were supplemented with $\mathrm{Na}_{2} \mathrm{SeO}_{3} 1 \mu \mathrm{M}$ (controls with no $\mathrm{Na}_{2} \mathrm{SeO}_{3}$ supplementation) and inoculated with stationary phase bacteria at a multiplicity of infection (MOI) of 100 ( 1 cell: 100 bacteria). SHK-1 cells not inoculated with bacteria were also cultured as an infection control $(n=3)$. After $24 \mathrm{~h}$, cells were washed twice with cold PBS and then incubated for 60 min with L-15 mediumplus gentamicin $(100 \mu \mathrm{g} / \mathrm{mL})$ to eliminate extracellular bacteria [23]. After incubation, cells were washed with PBS and incubated in an L-15 medium supplemented with or without $\mathrm{Na}_{2} \mathrm{SeO}_{3}$ as indicated above. To evaluate the cytopathic effect (CPE) caused by P. salmonis, SHK-1 cells were observed under an optical inverted phase contrast microscope AE31 (Motic, China) to follow the progression of the infection by image analysis (Moticam BTU10, Motic). Daily, for 10 days post-inoculation (dpi) with $P$. salmonis, images of cells of ten fields randomly obtained of each condition were used to count vacuoles. Cell viability was quantified using the trypan blue exclusion assay (Gibco) $(n=10)$. For bacterial quantification in infected SHK-1 cells, RNA was obtained from monolayers of infected SHK-1 cells and isolated by EZNA Total RNA kit I (OMEGA Bio-tek) and used as the template for reverse transcription reactions to synthesize cDNA using All-In-One 5X RT MasterMix (Amb), according to standard procedures. PCR conditions were $95{ }^{\circ} \mathrm{C}$ for 5 min followed by $94{ }^{\circ} \mathrm{C}$ for $15 \mathrm{~s}, 60^{\circ} \mathrm{C}$ for $15 \mathrm{~s}$ and $72{ }^{\circ} \mathrm{C}$ for $20 \mathrm{~s}$ for a total of 35 cycles using the primers F_Ps16S (5'-AGGGAGACTGCCGGTGATA-3') and R_Ps16S (5' ACTACGAGGCGCTTTCTCA $-3^{\prime}$ ) to amplify the RNA gene of $P$. salmonis (NR_025980.1). At least five replicates were performed for each $P$. salmonis quantification. 


\section{Immunofluorescence assay (IFAT)}

For IFAT, $1 \times 10^{3}$ SHK- 1 cells were seeded on coverslips $(n=3)$, treated, and infected as was described above. Then, cells were fixed with $4 \%$ paraformaldehyde in PBS for $30 \mathrm{~min}$, permeabilized with $0.1 \%$ saponin in PBS, and blocked with $0.1 \%$ saponin in PBS plus $3 \%$ BSA for $30 \mathrm{~min}$. Intracellular P. salmonis was detected by incubation with specific antibodies anti-P. salmonis (ANGO, USA) at 1:200 dilution for $1 \mathrm{~h}$ at room temperature. After three washes with PBS, cells were incubated with secondary anti-mouse FITC-conjugated antibody (Thermo Fisher Scientific, USA) at 1:200 dilution for $1 \mathrm{~h}$ and with phalloidin-Alexa 636 (Thermo Fisher Scientifi) at 1:200 dilution for $15 \mathrm{~min}$ to detect polymerized actin; and DAPI (4',6-diamidino-2-phenylindole, Thermo Fisher Scientific, 1:200 dilution) for $15 \mathrm{~min}$ to detect DNA. Preparations were observed in the Eclipse 50i epifluorescence microscope (Nikon, Japan) at $100 \times$ magnification under oil immersion [23]. The images obtained were processed with the Fiji Image J program (GNU General Public License).

\section{Experimental diets}

Three different diets were prepared using the commercial diet (BD) manufactured by Salmones Antártica (Puerto Montt, Chile) as the base for selenium (Se-yeast) supplementation by up to nominal final concentrations of 1,5 , and $10 \mathrm{mg}$ Se per $\mathrm{Kg}$ of diet (SSD1, SSD5, and SSD10, respectively). This allowed us to work outside the range of selenium deficiency and toxicity reported in rainbow trout in Hilton et al. [16]; Hunt et al. [17], and Pacitti et al. [24]. Briefly, Seyeast was homogenized manually in fish oil and incorporated into dry pellets using a laboratory vacuum coater (FoodSaver FFS003X, Oster, USA). Diets were formulated to be isoenergetic and isonitrogenous and to meet the National Research Council nutritional requirements for rainbow trout [25], where the only distinctive variable is the Se concentrations. The Se concentrations in diets were measured in triplicates by total $\mathrm{x}$-ray reflection fluorescent (TXRF) in an S2 PICOFOX system (Bruker, USA) following the manufacturer's instructions, according to Caruffo et al. [22]. Proximal composition analyses of the diet were performed at Instituto de Nutrición y Tecnología de los Alimentos (INTA, Universidad de Chile) according to the following procedures: dry matter was obtained after $24 \mathrm{~h}$ in an oven at $105^{\circ} \mathrm{C}$; ash by combustion at $450{ }^{\circ} \mathrm{C}$ for $16 \mathrm{~h}$, protein $\left(\mathrm{N}^{*} 6.25\right)$ by the Kjeldahl method; fat by Soxhlet method; and gross energy by the calorific factor (4, 9 and 4 for proteins, lipids, and carbohydrates, respectively). The detail of the dietary composition is in Additional file 1.

\section{Experimental animals and trial conditions}

Sixty juveniles rainbow trout (O. mykiss) were obtained from Salmones Antártica S.A (Puerto Montt, Chile). Fish were kept under a photoperiod of $14 \mathrm{~h}$ light and $10 \mathrm{~h}$ dark and acclimated for 10 days (fed with BD diet) to their experimental setup. Then, 20 fish were randomly distributed in three $200 \mathrm{~L}$ fiberglass tanks and fed with a daily ration of $2 \%$ of live weight (by hand-fed to visual satiation) divided into three equivalent portions (9:00 am, 1:00 pm, and 5:00 pm) with the experimental diets (SSD1, SSD5, and SSD10) for 8 weeks (60 days) at the Faculty of Agronomic Sciences Universidad de Chile. At the beginning of the study, there were no significant differences in weight between the tanks (Additional file 4). Each tank was supplied with $10 \mathrm{~L} / \mathrm{min}$ of freshwater at constant temperature $\left(15 \pm 1{ }^{\circ} \mathrm{C}\right)$. The water quality parameters were monitored daily and kept in normal ranges for salmonids: chlorine maximum tolerable levels $0 \mathrm{mg} / \mathrm{L}$, ammonium $<0.0125 \mathrm{mg} / \mathrm{L}$, nitrite $<1 \mathrm{mg} / \mathrm{L}$, nitrates $400 \mathrm{mg} / \mathrm{L}$ or more, total ammonia nitrogen $<1 \mathrm{mg} / \mathrm{L}$ and pH 6.5-7.2 according to Thorarensen and Farrell [26]. Also, oxygen was added to the system at a rate of $1 \mathrm{~L} / \mathrm{min}$ whenever it was necessary to maintain saturation levels above $8 \mathrm{mg} / \mathrm{L} \mathrm{O}_{2}$ or $\geq 90 \%$ oxygen saturation.

\section{Plasma biochemical profile and histopathological examination of the liver}

Blood samples and weight records were obtained at 0 and 60 days after the beginning of the feeding trial. The fish's final body weight from each tank was individually measured after anesthetized with tricaine methanesulphonate (Dolical 80\%, Centrovet, Chile). Five fish were then taken from each tank for blood sampling $(1 \mathrm{~mL})$ from the caudal vein using $5 \mathrm{~mL}$ syringes with $21 \mathrm{G}$ needles and collected in heparin tubes $\left(4 \mathrm{~mL}, \mathrm{BD}\right.$ Vacutainer $\left.{ }^{\circledR}, \mathrm{USA}\right)$. The blood of each fish was then centrifuged at $4{ }^{\circ} \mathrm{C}$ at $3000 \mathrm{~g}$ for $10 \mathrm{~min}$ (MIKRO 200R, Hettich, Germany) to obtain approximately $300 \mu \mathrm{L}$ of plasma that was assayed in an automatic biochemistry analyzer CM250 (Wiener Lab, Argentina) following the manufacturer's instructions to determine the plasma biochemical parameters. Alkaline phosphatase $(\mathrm{U} / \mathrm{L})$ and aspartate aminotransferase $(\mathrm{U} / \mathrm{L})$ concentrations were determined $(n=5)$. For the histopathological examination of the liver, five fish taken from each tank were euthanized with an overdose of Dolical 80\% (Centrovet) 60 days after the beginning of the feeding trial. One portion of each fish's liver was kept in formalin $10 \%$ at $\mathrm{pH} 7$ (Sigma-Aldrich) and were then rinsed with PBS and dehydrated in a graded series of ethanol, rinsed in xylene, infiltrated with paraffin, and 
embedded in paraffin blocks, according to Lee et al. [27]. Serial sections were prepared from each liver sample using a microtome (ModelRM2245, Leica Biosystems, Germany), placed on clean glass slides, dried at $40{ }^{\circ} \mathrm{C}$ for at least $48 \mathrm{~h}$, and then stained with hematoxylin-eosin (Thermo Fisher Scientific). After staining, five pictures were taken per treatment at $10 \times$ from five fields randomly obtained of each condition, using a digital camera Moticam BTU10 (Motic) under an optical inverted phase contrast microscope AE31 (Motic).

\section{Selenium content and oxygen radical absorbance capacity (ORAC) in trout plasma}

The quantification of Se in plasma at the end of the trial was performed by total $\mathrm{x}$-ray reflection fluorescent (TXRF) in an S2 PICOFOX system (Bruker) using $20 \mu \mathrm{L}$ of each plasma sampled following manufacturer's instructions ( $n=3$ fish per condition). The hydrophilic antioxidant capacity of the plasma was obtained by ORAC, according to Prior et al. [28] with modifications. Briefly, a working solution at $20.34 \mathrm{mg} / \mathrm{mL}$ of $2,2^{\prime}$-Azobis (2-amidinopropane) dihydrochloride (AAPH) (SigmaAldrich) and a working solution of sodium fluorescein (Life Technologies) at $8 \mathrm{nM}$ was prepared in phosphate buffer $75 \mathrm{mM}$ (pH 7.4) (buffer A). $150 \mu \mathrm{L}$ of sodium fluorescein solution was added at each experimental well, while blank wells received $25 \mu \mathrm{L}$ of buffer A. Standards Trolox (Sigma-Aldrich) calibration curve $(6.25,12.5,25$, $50,100 \mathrm{mM}$ ) were pipetted into appropriate wells and samples received $25 \mu \mathrm{L}$ of the sample. The 96 well plate (Thermo Fisher Scientific) was then incubated for $30 \mathrm{~min}$ at $37^{\circ} \mathrm{C}$ to equilibrate. A plate reader injector system with $5 \mathrm{~mL}$ of AAPH solution was used just before adding to the preincubated microplate, and reactions were initiated by adding $25 \mu \mathrm{L}$ of AAPH solution. All ORAC analyses were performed on a synergy HTX (BioTek Instruments, USA) using an excitation wavelength of $493 \mathrm{~nm}$ and an emission filter of $515 \mathrm{~nm}$, and ORAC values were calculated as described by Cao and Prior [28, 29], from five technical replicates.

\section{Ex vivo infection assay}

To evaluate the effect of plasma from trout fed with different concentrations of selenium in the diets over the infection of SHK-1 cells with P. salmonis, we first inactivated the plasma by heat following the recommendations described by Sakai [30], making modifications such as changing the temperature to $46^{\circ} \mathrm{C}$ for $15 \mathrm{~min}$. Then, we determined the maximum heat-inactivated plasma concentration for supplementing the SHK-1 medium without affecting its viability or promoting the growth of $P$. salmonis. Under the cellular culture conditions described above, SHK-1 cells were supplemented with $0,2,4,6$, and
$8 \%$ of trout plasma for 12 days (without selenium supplementation) $(n=3)$. In parallel, the culture medium of $P$. salmonis was supplemented with the same plasma concentrations to evaluate the bacterial growth for seven days. Media supplementation with $2 \%$ heat-inactivated trout plasma did not affect the viability of the cells or bacteria; hence this concentration was used in the following assays. Thus, to evaluate the effect of plasma from trout fed with the SSD1 and SSD5 diets over the in vitro infection of SHK-1 cells with P. salmonis, $2 \%$ of heat-inactivated FBS was supplemented with $2 \%$ of heat-inactivated trout plasma (pool of five fish from each condition) or $2 \%$ of heat-inactivated FBS (FBS-control). The in vitro infection was monitored daily, and after 10 days postinfection, cell viability was determined by trypan blue $(n=10)$. To evaluate the cytopathic effect (CPE) caused by $P$. salmonis, SHK-1 cells were stained with hematoxylin-eosin (H\&E) according to Caruffo et al. [22], and observed under an optical inverted phase contrast microscope AE31 (Motic) to follow the progression of the infection by image analysis (Moticam BTU10, Motic). Six photos were taken in a random field captured at 10X. The number of total cells (nucleus per field), infected cells (cells with at least one vacuole), and vacuoles (cytopathic effect of the infection) were counted in each image for each condition. Also, the area (length"width) was measure with ImageJ (Java). At least three replicates were performed for each infection assay.

\section{Statistical analysis}

Statistical analysis was performed using the GraphPad Prism 8.0.2 program (GraphPad Software, Inc). Differences in bacterial growth, cell viability, and relative $P$. salmonis load using different selenium concentrations and at different sampling points were analyzed using a two-way analysis of variance (ANOVA) followed by Bonferroni comparison test. Differences in bacterial growth, CPE cells/total cells, and $P$. salmonis-containing vacuoles (PCV) area obtained at a specific time point and a defined selenium concentration were analyzed using oneway ANOVA and Tukey multiple comparisons test. The results are presented as the mean \pm standard deviation (SD). $P$-value $<0.05$ was considered significant.

\section{Results}

Selenium increases the abundance and activity of Gpx1 at non-bactericidal and non-cytotoxic concentrations in SHK-1

To evaluate selenium's effect over the host-pathogen relation and not over the host or pathogen viability, we determined the maximum concentration of sodium selenite that did not generate a cytotoxic or bactericidal effect in SHK-1 and P. salmonis, respectively. We grew 
bacteria and cells independently with sodium selenite supplements at different concentrations $(0-100 \mu \mathrm{M})$ for 12 days. Sodium selenite showed no bactericidal effect when $P$. salmonis was grown at concentrations ranging from 0 to $4 \mu \mathrm{M}$. However, we observed antiproliferative effects at concentrations equal or higher to $6 \mu \mathrm{M}$ from the third day of culture ( $p$-value $<0.05$; Figure $1 \mathrm{~A})$. Similarly, we did not record effects on the cell viability of SHK-1 at concentrations below $1.5 \mu \mathrm{M}$, while concentrations equal or higher to $2 \mu \mathrm{M}$ showed reduced cell viability in a dose- and time-dependent manner $(p$-value $<0.05$; Figure 1B). Therefore, the maximum concentration evaluated that did not cause a reduction in the proliferation of P. salmonis, or the viability of SHK- 1 was $1 \mu \mathrm{M}$ of sodium selenite; thus, this concentration was selected to perform the following in vitro experiments.

To determine the effect of sodium selenite on the mRNA abundance and activity of the selenoprotein glutathione peroxidase 1 (Gpx1) in SHK-1, we measured the abundance of the gpx1 transcript by qPCR and the enzymatic activity of $\mathrm{Gpx} 1$ by spectrophotometry. The results indicated that the supplementation of $1 \mu \mathrm{M}$ of sodium selenite increased the relative abundance of gpx $1 \mathrm{mRNA}$ by $121.4 \%(2.2 \mathrm{AU})$ and the enzymatic activity of Gpx1 by $145.37 \%$ ( 2.5 enzyme activity) after $24 \mathrm{~h}$ of exposure ( $p$-value $<0.05$; Figure $1 C$ ) when compared to the nonsupplemented control.

\section{Selenium reduces Piscirickettsia salmonis infection in SHK-1}

To investigate whether selenium exerts a protective effect on infection, we performed an in vitro infection assay with SHK-1 cells with or without sodium selenite $(1 \mu \mathrm{M})$ and challenged with $P$. salmonis. For 10 days, we characterized the infection according to the cytopathic effect (CPE) exhibited by the infected cells, a phenomenon described by the presence of replicative vacuoles containing $P$. salmonis (PCV) in SHK-1. The results indicated that infected cells supplemented with selenium showed a significant decrease of vacuolization ( $p$-value $<0.05$, Figure $2 \mathrm{~A}$ and Additional file 2) compared to infected cells not supplemented with selenium at 10 days post-infection. As we expected, this result correlated with a decrease in the bacterial load ( $p$-value $<0.05$, Figure $2 \mathrm{~B})$. Interestingly, this reduced infectious cytopathic effect in the presence of selenium was observed from $5 \mathrm{dpi}$ and was maintained until the end of the trial ( $p$-value $<0.05$, Additional file 2). Moreover, the infected SHK-1 cells reduced their viability up to $60.1 \%$ relative to uninfected control cells in the absence of selenium; however, when the medium was supplemented with selenium, the infected cells reduced their viability only a $37.7 \%$ ( $p$-value $<0.05$, Figure 2B). Thus, a significant increase in cell viability

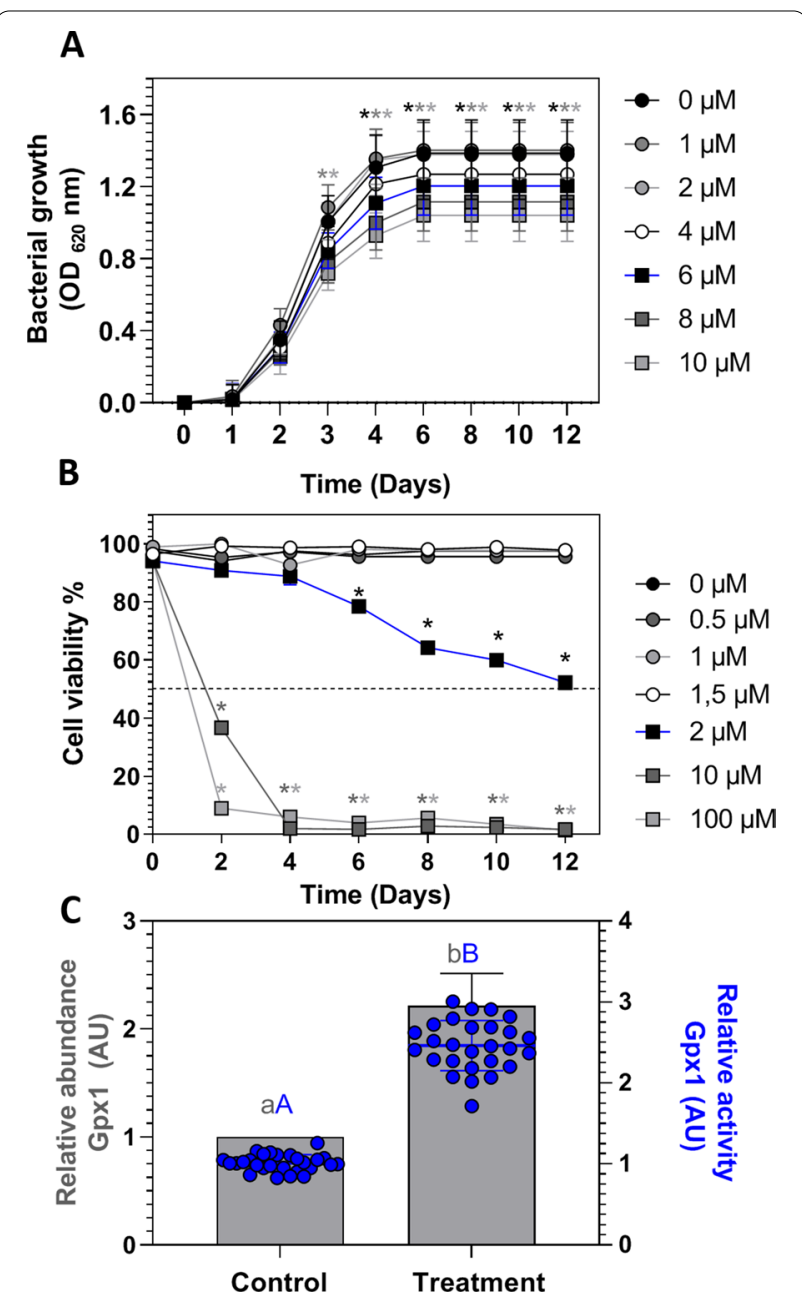

Figure 1 Effect of sodium selenite on SHK-1 cell viability and P. salmonis growth. A SHK-1 viability at different concentrations of sodium selenite supplemented in L-15 medium. B Bacterial growth of $P$. salmonis at different concentrations of sodium selenite supplemented in SRS broth. For A and B, experiments were performed for 12 days post-treatment (dpt). Each circle and square represent the mean \pm SD of ten observations measured in at least two independent experiments. Bidirectional ANOVA and subsequent Bonferroni comparison test were performed with respect to the control $\left(0 \mu \mathrm{M} \mathrm{Na}_{2} \mathrm{SeO}_{3}\right)$. Colored asterisks indicate significant differences ( $p$-value $<0.05$ ) for de different condition. C Relative abundance (arbitrary units) and activity of glutathione peroxidase 1 (Gpx1). The glutathione peroxidase 1 experiment was carried out $24 \mathrm{~h}$ after treatment. The bars represent the means \pm SD of the relative abundance measured in at least three independent experiments by qPCR, while the dispersion points show the glutathione peroxidase 1 activity as a result of 32 measures in at least two independent experiments. A Student $t$-test was performed for unpaired data between groups. Letters $(a, A, b$ and $B$ ) indicate significant differences (p-value $<0.05)$

in response to sodium selenite supplementation was observed in infected cells $(p$-value $<0.05)$. Representative images of this phenomenon are shown in the 


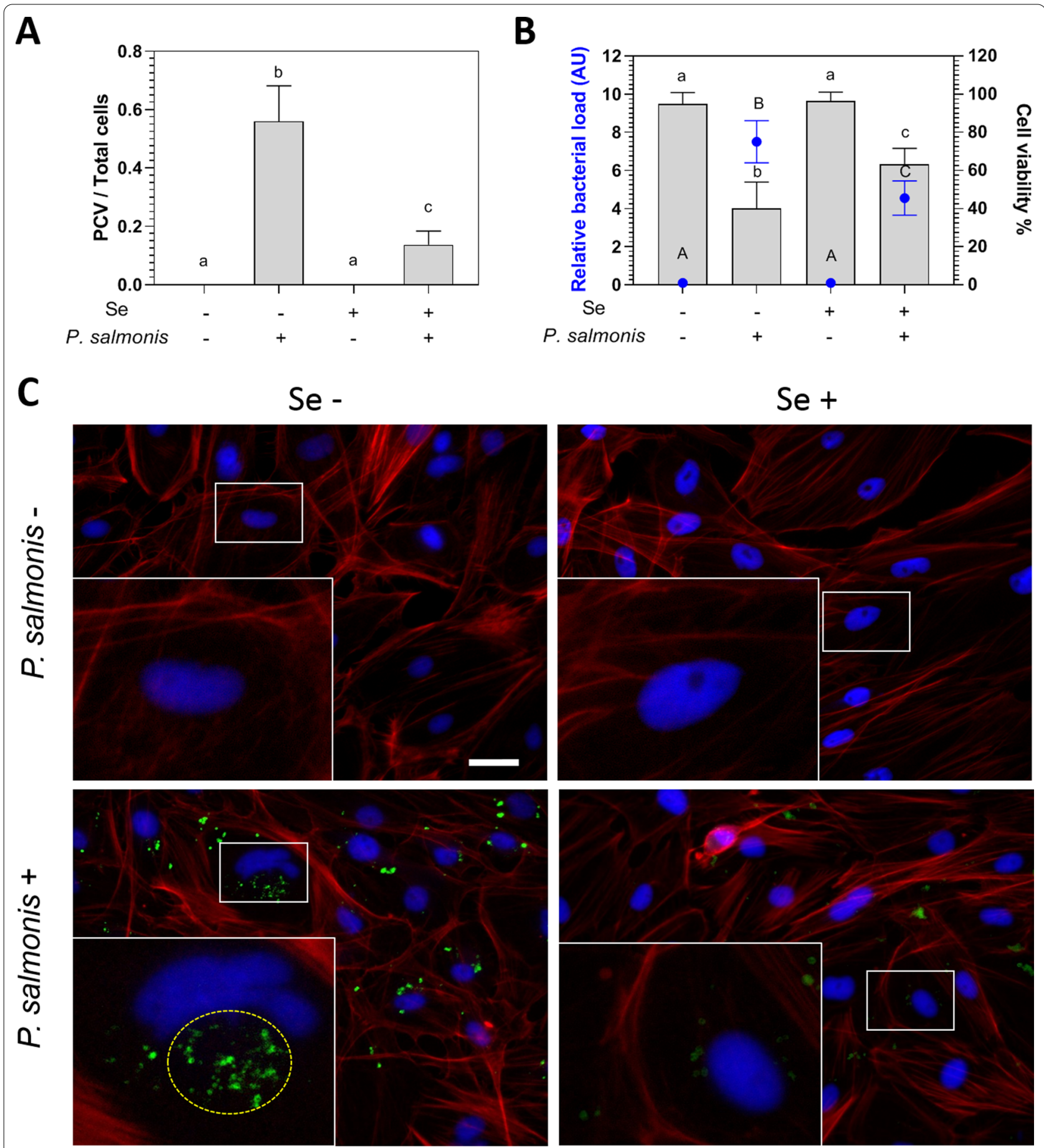

Figure 2 Effect of sodium selenite in the viability of SHK-1 cells infected with P. salmonis. A P. salmonis containing vacuoles (PCVs) per total cells in SHK-1 sodium selenite treated/untreated and infected/uninfected cells at 10 days post-infection (dpi). B Relative P. salmonis load (arbitrary units, AU) (left axis) represented by blue circles and cell viability percentage (right axis) in grey bars in SHK-1 sodium selenite treated/untreated and infected/uninfected cells. C Representative immunofluorescence microphotographs of SHK-1 monolayer exposed (Se +) or not (Se -) to sodium selenite $(1 \mu \mathrm{M})$. Upper panels show uninfected cells, and lower panels show P. salmonis infected cells at $10 \mathrm{dpi}$ with sodium selenite treatment. $\mathrm{Bar}=10 \mu \mathrm{m}$. For B and C, data represent mean \pm SD of 10 observations measured in at least two independent experiments $(n=10)$. One-way ANOVA and Tukey multiple comparisons between all treatments were performed. Different letters represent significant differences ( $p$-value $<0.05$; capital letters for left axis and lowercase letters for right axis comparisons). 
immunofluorescence of Figure 2C, in which a reduced bacterial load (green) and a decrease in PCVs (yellow dotted line) were observed in the presence of supplemented selenium ( $p$-value $<0.05)$. The control shows how the marked PCV displaced the cell nucleus (Figure $2 \mathrm{C}$ ), which is not observed in cells treated with selenium. Altogether, these results indicate that sodium selenite, at a non-antibiotic and non-cytotoxic concentration, reduces the cytopathic effect, bacterial load, and mortality of SHK-1 cells infected with P. salmonis. Besides, the results suggest that selenium exerts a protective effect by increasing the abundance and activity of glutathione peroxidase in SHK-1 infected with $P$. salmonis.

\section{Dietary selenium increases the plasma concentration of selenium and its antioxidant capacity in rainbow trout} To determine the effect of selenium on O. mykiss physiological parameters, fish were fed with selenium supplemented diets at three different concentrations: 1, 5, and $10 \mathrm{mg}$ Se per Kg of diet (diets SSD1, SSD5, and SSD10, respectively) for 60 days. The livers of fish fed with SSD10 presented changes in pigmentation and friability at 30 days post-treatment (dpt), but not the livers of fish fed with diets SSD1 and SSD5 (data not shown). For this reason, at the end of the trial $(60 \mathrm{dpt})$, we performed a liver histopathology assay of each condition. Representative images of the histopathology are shown in Figure 3A. The livers of fish fed with SSD1 and SSD5 had a normal phenotype, while the liver of fish fed with diet SSD10 showed signs of mononuclear cell infiltration, suggesting an inflammatory reaction associated with the consumption of a diet supplemented with $10 \mathrm{mg}$ of Se per kilogram of diet. To determine if this structural observation correlated with a functional effect on hepatic enzymes, we carried out plasma determination of alkaline phosphatase (ALP) and aspartate aminotransferase (AST) activity, both markers of hepatic damage. Despite mononuclear cell infiltration, we did not observe significant differences in AST activity among the three diets. In contrast, ALP activity significantly decreased in SSP10 compared to SSP5, but not to SSP1 ( $p$-value $<0.05$, Figures $3 \mathrm{~B}$ and C).

In addition, we measured the plasma concentration of selenium by Total X-ray fluorescence spectroscopy (TXRF) in fish fed with the different experimental diets. This result indicated that only diet SSD5 but not SSD10 increased the plasma selenium concentration compared to diet SSD1 ( $p$-value $<0.05$, Figure 3D). Interestingly, this increment of selenium correlated with a higher hydrophilic antioxidant capacity in the plasma of fish fed with diet SSD5 ( $p$-value $<0.05$, Figure 3E).
High concentrations of trout plasma and selenium supplementation affects the bacterial growth and viability of SHK-1

To determine the maximum concentration of plasma that did not generate a bactericidal nor a cytotoxic effect in the cells of $P$. salmonis and SHK-1 cells, we first cultivated independently the bacterium and SHK-1 cells with different concentrations $(0,2,4,6$, and $8 \%)$ of plasma from fish fed without selenium supplementation. Remarkably, bacterial growth in supplemented medium with plasma concentrations higher than $4 \%$ significantly increased $P$. salmonis growth compared to a non-supplemented medium ( $p$-value $<0.05$, Additional file 3 ). Contrarily, cellular medium supplemented with plasma concentrations equal or superior to $4 \%$ significantly decreased SHK-1 cell viability ( $p$-value $<0.05$, Additional file 3 ). Hence, we selected a $2 \%$ concentration of plasma supplementation since it did not affect the normal growth of both the bacterium and SHK-1. Then, for determining the effect of the different concentrations and antioxidant capacity of selenium in plasma, we cultured the bacterium and SHK-1 cells with a supplement of $2 \%$ of trout plasma from fish fed with diets of 1 (SSP1), 5 (SSP5), or 10 (SSP10) mg Se/ $\mathrm{Kg}$ and compared their growth to bacteria and SHK-1 cells cultured in media non-supplemented with fish plasma (FBS). The results indicated that despite plasma non-supplemented with selenium at $2 \%$ did not affect the bacterium and SHK-1 cells' growth, SSP10 significantly decreased the growth and cell viability compared with the other conditions ( $p$-value $<0.05$, Figure 4$)$. Interestingly, the medium supplemented with SSP1 and SSP5 did not show effects on the viability of SHK-1 compared to cells grown in FBS. Nevertheless, SSP1 and SSP5 showed an increase in the growth of $P$. salmonis compared to bacteria grown in a microbiological medium not supplemented with trout plasma (FBS). Since SSP10 displayed an antiproliferative and cytotoxic effect, it was discarded for future assays.

\section{Selenium supplemented trout plasma reduces Piscirickettsia salmonis infection in SHK-1}

Due to the high costs of performing an infection challenge in fish (in vivo), we developed an ex vivo assay to evaluate the effect of dietary selenium on fish cells in response to infections with $P$. salmonis. By doing so, we characterized the infection phenotype of $P$. salmonis infecting SHK-1 cells grown in non-supplemented (FBS) or supplemented cell culture media with $2 \%$ of SSP1 and SSP5. A significant decrease in the total number of infected cells (65.74\% of reduction) and the presence of PCV (64.33\% of reduction) was observed in cells treated with SSP5, but not with SSP1, when infected 
A
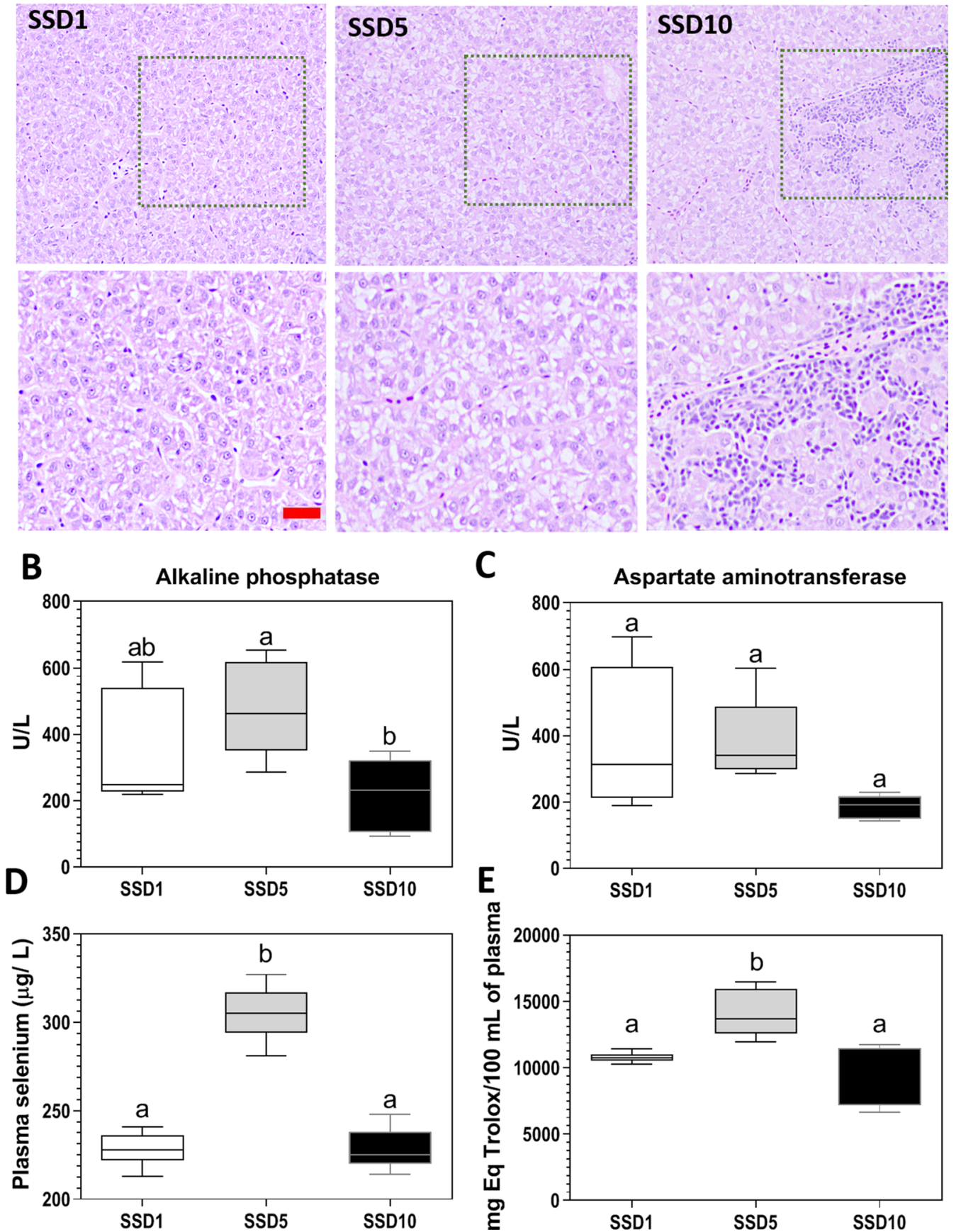

Figure 3 Effect of the selenium supplemented diets on O. mykiss physiological traits. A Representative images of livers with hematoxylineosin staining of fish fed with the experimental diets SSD1, SSD5, and SS10, and their respective digital zoom of 10\%. Bars $=10 \mu \mathrm{m}$. B and $\mathbf{C}$ Biochemical measurements of enzymes indicative of liver damage $(n=5)$. D Plasma selenium concentration of $O$. mykiss fed with different concentrations of selenium in the diet measured by Total X-ray fluorescence spectroscopy (TXRF) at 60 days post-treatment (dpt) $(n=3)$. $\mathbf{E}$ Hydrophilic antioxidant capacity in plasmas from O. mykiss fed with different selenium concentrations in the diet measured by oxygen radical antioxidant capacity (ORAC) assay at $60 \mathrm{dpt}(n=5)$. Different letters represent significant differences (ANOVA $p<0.05$, post hoc analysis Tukey). 


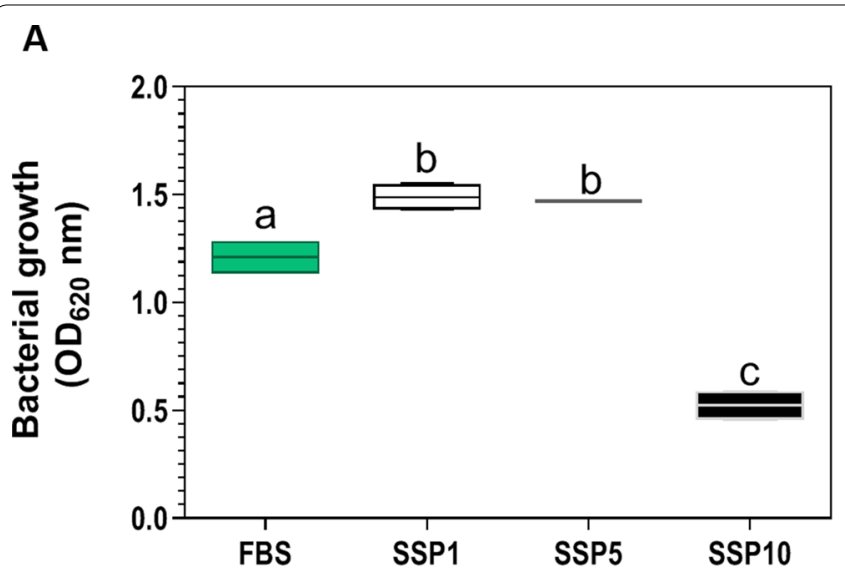

B

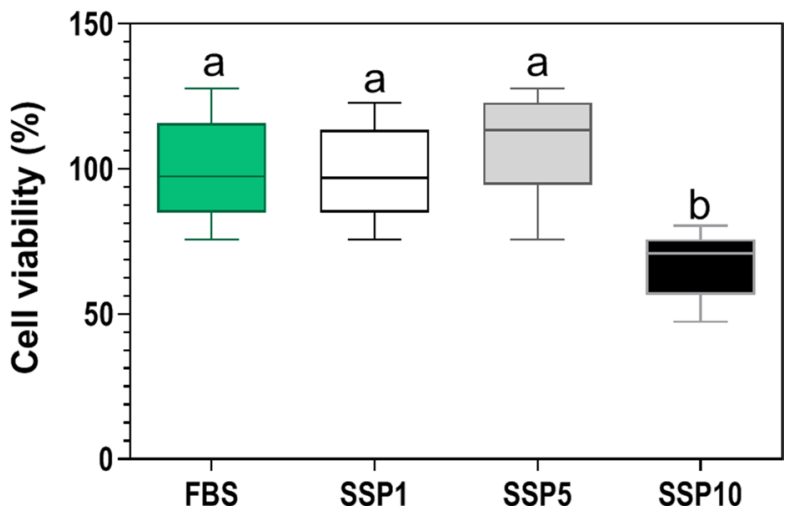

Figure 4 Effect of plasma of O. mykiss fed with different selenium supplemented diets on $P$. salmonis bacterial growth and SHK-1 viability. A Growth of P. salmonis in SRS-broth medium with selenium supplemented plasma (SSP) from O. mykiss fed with the SSD1, SSD5, or SSD10 (pool of five fish per condition) and using SRS-broth medium as a control (FBS). B Cell viability of SHK-1 cells in Leivobitz L-15 medium with selenium supplemented plasma (SSP) from O. mykiss fed with the SSD1, SSD5, or SSD10 (pool of five fish per condition) and using SRS-broth medium as a control (FBS). One-way ANOVA and Tukey multiple comparisons between all treatments were performed $(p$-value <0.05). with P. salmonis and compared to non-treated cells (FBS) ( $p$-value $<0.05$, Figures $5 \mathrm{~A}-\mathrm{C})$. Moreover, infected cells treated with SSP5 also reduced the total number of infected cells (62.09\% of reduction) and the presence of PCV (62.35\% of reduction) compared with cells treated with SSP1 ( $p$-value $<0.05$, Figures $5 \mathrm{~A}-\mathrm{C})$. Interestingly, SHK-1 treated with SSP5 also significantly decreased PCV size compared to FBS and SSP1 (33.80\% and 32.91\% of reduction, respectively), suggesting a reduction in the infection progression. As we expected, these reduced CPEs correlated with a significant decrease in bacterial load ( $p$-value $<0.05$, Figure 5D). Finally, infected SHK-1 cells non treated with SSP significantly reduced their viability in comparison with non-infected SHK-1 cells (52.21\% of reduction), while infected SHK-1 cells treated with SSP1 or SSP5 improved cell viability compared to infected non treated SHK-1 cells $(27.85 \%$ and $57.85 \%$ of improvement, respectively) ( $p$-value $<0.05$, Figure $5 \mathrm{D}$ ). Taken together, these results indicate that selenium, at a non-antibiotic and non-cytotoxic concentration, reduces the cytopathic effect, the infection progression, and the mortality of SHK-1 cells infected with P. salmonis.

\section{Discussion}

Piscirickettsiosis is the most relevant infectious disease afflicting the Chilean salmon farming industry. The observed high incidence of infectious events in farms reinforces the need to generate alternative strategies to fight this disease. In this way, the use of host-directed antimicrobial drugs or micronutrients to combat intracellular bacteria like $P$. salmonis can be an opportunity to avoid the excessive use of antibiotics and their consequent effects, such as microbial resistance $[6,31$, 32]. This approach allows the perturbation of host pathways used by intracellular pathogens to reproduce inside host cells, improving the defensive response by circumventing the infection and/or repressing its effects. Previous investigations on the transcriptomic response of salmonids to $P$. salmonis infection support identifying critical biological processes and pathways that are good candidates to be manipulated by this strategy $[8,9,33]$, highlighting the antioxidant host metabolism.

It has been widely described that macrophages respond to the infection by producing reactive oxygen species (ROS); however, ROS is also deleterious for the host cell. Hence, an adequate antioxidant system can support this redox homeostasis based on its enzymatic machinery activity, part of which is dependent on the selenium status [34]. Selenium is an effective nutritional antioxidant that carries out biological effects by its incorporation into selenoproteins. It has been proven through various studies that selenium has a role in the immune response of different species by the regulation of the redox state of cells, influencing inflammation and immune responses [35-37]. In fish, it has been described that Chinook salmon infected with the intracellular bacterium Renibacterium salmoninarum have significantly increased their mortality when fed with selenium-deficient diets compared to a seleno-sufficient diet [15]. Selenium deficit has also been shown to correlate with increased mortality in channel catfish exposed to the intracellular bacterium Edwardsiella ictaluri [14]. Although no specific studies have been done to evaluate the effect of dietary selenium 


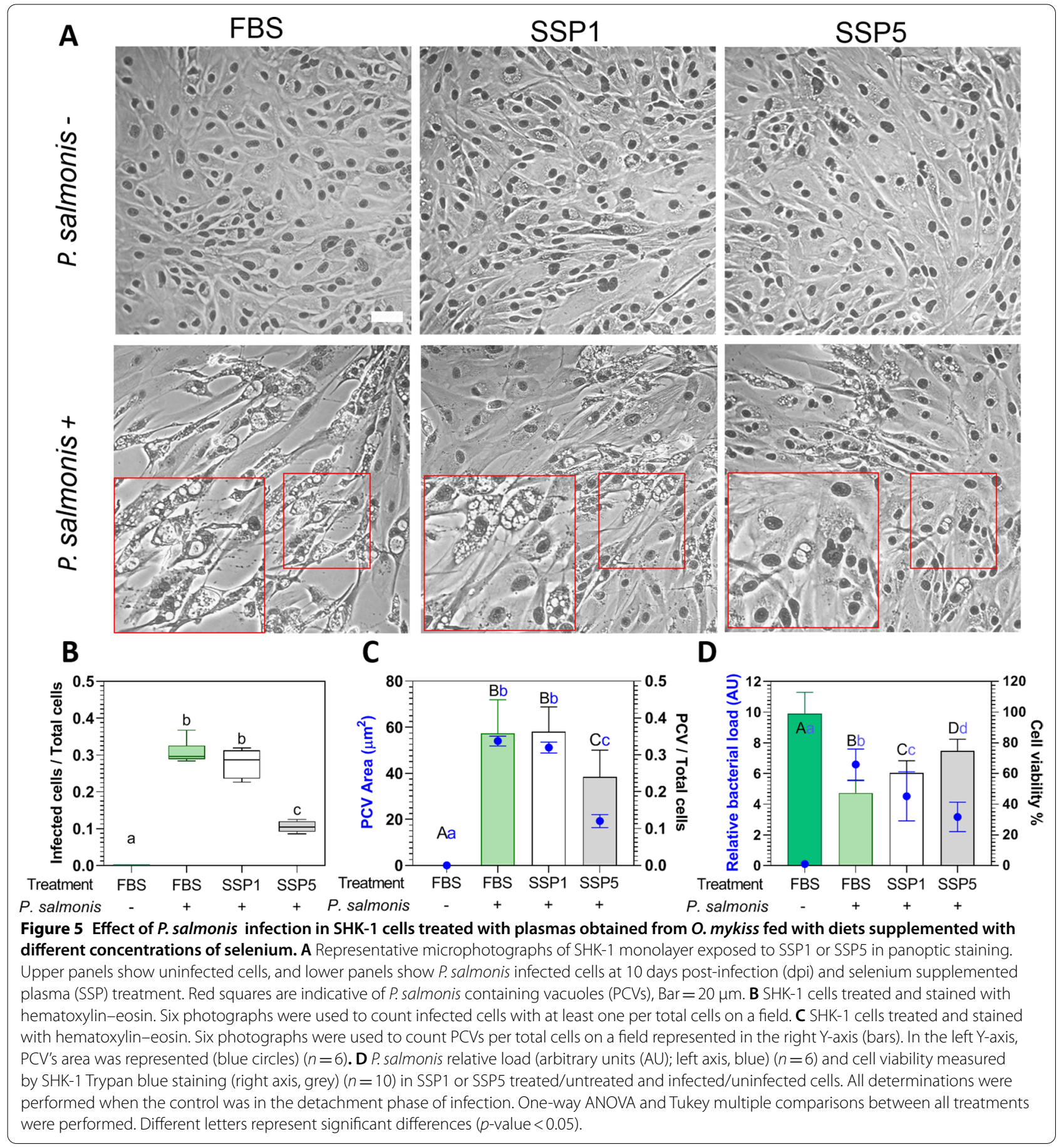

on salmonids' response to infection with $P$. salmonis, it has been reported that several selenoproteins are consistently differentially expressed in response to the infection with this bacterium [8-10]. Therefore, we hypothesized that selenium supplementation at the host's cellular level may affect the intracellular infection of $P$. salmonis at non-antibiotic concentrations.
Our results indicated that the classic cellular marker of selenium status, Gpx1, increased its transcript abundance and activity in the SHK-1 supplemented in vitro with selenium at non-bactericidal nor cytotoxic concentrations ( $p$-value $<0.05$, Figure 1$)$. Besides, selenium's dietary supplementation, at a non-toxic concentration, increased the selenium concentration and antioxidant 
capacity in trouts' plasma ( $p$-value $<0.05$, Figure 3 ). Interestingly, direct selenium supplementation in SHK-1 cells correlated with a decreased intracellular bacterial proliferation and an increased protective capacity against $P$. salmonis infection in vitro ( $p$-value $<0.05$, Figure 2$)$. This result was recapitulated when we supplied plasma from trouts fed with the SSD5 (ex vivo) to SHK-1 cells infected with $P$. salmonis at non-bactericidal nor cytotoxic concentrations ( $p$-value $<0.05$, Figures 4 and 5 ). These results emphasize the contribution of cellular models as an approach to evaluate the effects of micronutrients, such as selenium, in future applications to avoid or reduce the high costs of challenge test trials in fish.

The present report also highlights that the dietary modulation of host selenium levels must be performed with a slight adjustment, considering the risk of selenium toxicity for fundamental processes and growth traits. In this way, even though the SSD10 was under the selenium toxicity level previously described [16, 17, 24, 38], this diet generated infiltration of mononuclear cells in the liver of fish as a sign of early inflammation [39, 40] and was detrimental for the growth performance in the in vivo assay (Additional file 4). Although our objective was not to evaluate the effect of selenium on fish's growth, our toxicity evaluation tests allowed us to observe that SSD5 significantly improved their growth compared to fish fed with SSD1 and SSD10 diets (Additional file 4), as has been recently reported by Wang et al. in 2018 [41].

Currently, Chilean aquaculture uses organic selenium in the form of selenium-yeast to supplement the salmonids' diets at a concentration average of $1 \mathrm{mg} \mathrm{Se} / \mathrm{Kg}$, representing the minimum concentration required to avoid a deficit in fish' growth [16]. However, our results suggest that concentrations up to 5 times higher in a dietary selenium supplementation (SSD5) could improve fish response to $P$. salmonis infection and its growth performance. This observation highlights that micronutrient supplementation in the fish diet should be evaluated beyond compliance with the minimum nutritional requirements and consider other aspects like the optimal response to pathogens.

To the best of our knowledge, this is the first report demonstrating the protective capacity of selenium against $P$. salmonis infection in salmonids' macrophages. In this way, we can highlight the role that selenium plays in salmonids' nutrition and immunological status and how an adequate supplementation of trace minerals can improve hosts' response to intracellular pathogens, such as $P$. salmonis. Although our results show that selenium could control $P$. salmonis infection at non-antibiotic concentrations, we cannot rule out that it may exert an inhibitory activity on bacterial virulence. This aspect will be evaluated in future trials.
Finally, given the increasing prevalence of antibiotic resistance, our results collectively offer the possibility to combat SRS, and maybe other fish infections, by increasing selenium at non-antibiotic and non-toxic concentrations as a dietary adjuvant therapy to reduce the use of antibiotics.

\section{Supplementary Information}

The online version contains supplementary material available at https://doi. org/10.1186/s13567-021-00930-0.

Additional file 1. Ingredient formulation and nutrient composition of the basal experimental diet. In the present study, three experimental diets were prepared by supplementing by up to 1, 5, and $10 \mathrm{mg} / \mathrm{kg} \mathrm{Se}$ from selenium-yeast to the basal diet (BD). The resulting diets were the selenium supplemented diet 1 (SSD1), selenium supplemented diet 5 (SSD5), and selenium supplemented diet 10 (SSD10). SGR, specific growth rate. FCR, feed conversion ratio. Values are represented as mean $\pm S D$. One-way ANOVA and Tukey multiple comparisons between all treatments were performed ( $p$-value $<0.05$ ). In each line, different letters indicate significant differences between treatments.

Additional file 2. Effect of sodium selenite on SHK-1 cells infected with $P$. salmonis. A. Representative brightfield images of SHK-1 monolayer exposed $(\mathrm{Se}+$ ) or not (Se -) to sodium selenite (1 $\mu \mathrm{M})$. Upper panels show uninfected cells, and lower panels show cells infected with P. salmonis at 10 days post-infection (dpi) and sodium selenite treatment. Bar $=20 \mu \mathrm{m}$. B. P. salmonis containing vacuoles (PCVs) per total cells in the field represented by boxes in SHK-1 sodium selenite treated/untreated and infected/uninfected cells at $10 \mathrm{dpi}$. The data represent mean $\pm \mathrm{SD}$ of 10 observations measured in at least two independent experiments $(n=10)$. Bidirectional ANOVA and Bonferroni multiple comparisons between all treatments were performed ( $p$-value $<0.05)$. Asterisks indicate significant differences.

Additional file 3. Determination of the maximum concentration of plasma with no bactericidal nor cytotoxic effects on P. salmonis and SHK-1 cells. A. Seven days post-treatment (dpt) growth of $P$. salmonis in SRS-broth medium with different wild-type plasma concentrations from O. mykiss. $(n=3)$. B. Supplementation of Leibovitz L-15 medium with trout plasma in SHK-1 cell $(n=3)$. For A and B, one-way ANOVA and Tukey multiple comparisons between all treatments were performed ( $p$-value $<0.05$ ). Different letters indicate significant differences.

Additional file 4. Parameters of rainbow trout fed with selenium supplemented diets for 60 days. SGR, specific growth rate. FCR, feed conversion ratio. Values are represented as mean $\pm S D$ ( $n=5$ fish). Different letters indicate significant differences between treatments One-way ANOVA and Tukey multiple comparisons between all treatments were performed ( $p$-value $<0.05)$.

\section{Acknowledgements}

We want to thank Raquel Becerra and Mario Caruffo for their support and technical advice during the investigation.

\section{Authors' contributions}

RP and JW: Conceptualization; RP, JW, JPV, MM: Methodology; JPV, MM, ICB, FVT, LM, DO,PS, Validation; JPV, MM, JW, RP: Formal analysis; JPV, MM, JW, RP: Investigation; RP and JW: Resources; JPV, MM, JW, RP: Data curation; JPV, MM, JW, RP: Writing—original draft; JPV, MM, ICB, FVT, LM, DO, PS, DM, JW, RP: Writing — review \& editing; JW, RP: Project administration; DM, JW, RP: Supervision; RP, JW, DM: Funding acquisition. All authors read and approved the final manuscript.

\section{Funding}

This study was carried out under the framework of the following programs and Grants: FONDECYT \#11161083 and Enlace VID ENL18/20 (RP); FONDEF \#ID16i10274 (JW); FONDECYT\#11200319 (DM). 


\section{Declarations}

\section{Ethics approval and consent to participate}

All the experiments regarding fish were performed following the National Institutes of Health guide for the care and use of Laboratory animals (NIH Publications No. 8023, revised 1978) and in accordance with the Institutional Committee for the Care and Use of Animals (CICUA), of the Vice-rectory for Research and Development of the University of Chile; CICUA: 2016-44.

\section{Competing interests}

The authors declare that they have no competing interests.

\begin{abstract}
Author details
'Laboratorio de Genómica y Genética de Interacciones Biológicas (LG2|B), Instituto de Nutrición y Tecnología de los Alimento, Universidad de Chile, El Líbano, Macul, 5524 Santiago, Chile. ${ }^{2}$ Center for Research and Innovation in Aquaculture (CRIA), Universidad de Chile, Santiago, Santiago, Chile. ${ }^{3}$ Laboratorio de Nutrición Animal (LABNA). Facultad de Ciencias Agronómicas, Producción Animal, Universidad de Chile, 11315 Santa Rosa, La Pintana, Chile. ${ }^{4}$ GEMA Center for Genomics, Ecology and Environment, Universidad Mayor, Camino La Pirámide, 5750 Huechuraba, Santiago, Chile.
\end{abstract}

Received: 23 January 2021 Accepted: 23 March 2021

Published online: 01 May 2021

\section{References}

1. SUBPESCA (2019) Informe sectorial de pesca y acuicultura. https://www. subpesca.cl/portal/618/articles-104507_documento.pdf. Accessed 17 Jan 2021

2. Calquín P, Ruiz P, Oliver C, Sánchez P, Haro R, Oliva H, Vargas-Chacoff L, Avendaño-Herrera R, Yáñez AJ (2018) Physiological evidence that Piscirickettsia salmonis produces siderophores and uses iron from different sources. J Fish Dis 41:553-558. https://doi.org/10.1111/jfd.12745

3. McCarthy ÚM, Bron JE, Brown L, Pourahmad F, Bricknell IR, Thompson KD, Adams A, Ellis AE (2008) Survival and replication of Piscirickettsia salmonis in rainbow trout head kidney macrophages. Fish Shellfish Immunol 25:477-484. https://doi.org/10.1016/j.fsi.2008.07.005

4. FAO (2012) Improving biosecurity through prudent and responsible use of veterinary medicines in aquatic food production

5. Saavedra J, Grandón M, Villalobos-González J, Bohle H, Bustos P, Mancilla M (2018) Isolation, functional characterization and transmissibility of p3PS10, a multidrug resistance plasmid of the fish pathogen Piscirickettsia salmonis. Front Microbiol 9:923. https://doi.org/10.3389/fmicb.2018. 00923

6. Kaufmann SHE, Dorhoi A, Hotchkiss RS, Bartenschlager R (2018) Hostdirected therapies for bacterial and viral infections. Nat Publ Gr 17:35-56. https://doi.org/10.1038/nrd.2017.162

7. Rise ML, Jones SRM, Brown GD, Von Schalburg KR, Davidson WS, Koop BF (2004) Microarray analyses identify molecular biomarkers of Atlantic salmon macrophage and hematopoietic kidney response to Piscirickettsia salmonis infection. Physiol Genomics 20:21-35. https://doi.org/10.1152/ physiolgenomics.00036.2004

8. Tacchi L, Bron JE, Taggart JB, Secombes CJ, Bickerdike R, Adler MA, Takle H, Martin SAM (2011) Multiple tissue transcriptomic responses to Piscirickettsia salmonis in Atlantic salmon (Salmo salar). Physiol Genomics 43:1241-1254. https://doi.org/10.1152/physiolgenomics.00086.2011

9. Pulgar R, Hödar C, Travisany D, Zuñiga A, Domínguez C, Maass A, González M, Cambiazo V (2015) Transcriptional response of Atlantic salmon families to Piscirickettsia salmonis infection highlights the relevance of the iron-deprivation defence system. BMC Genomics 16:495. https://doi.org/10.1186/s12864-015-1716-9

10. Pedro AVF, Martínez D, Pontigo JP, Vargas-Lagos C, Hawes C, Wadsworth S, Morera FJ, Vargas-Chacoff L, Yáñez AJ (2019) Transcriptional activation of genes involved in oxidative stress in Salmo salar challenged with Piscirickettsia salmonis. Comp Biochem Physiol B Biochem Mol Biol 229:18-25. https://doi.org/10.1016/j.cbpb.2018.12.004

11. Reich HJ, Hondal RJ (2016) Why nature chose selenium. ACS Chem Biol 11:821-841. https://doi.org/10.1021/acschembio.6b00031
12. Yang GQ (1985) Keshan Disease: an endemic selenium-related deficiency disease. in "Trace Element Nutrition in Children, Nestle Nutrition", R.K. Chandra ed., Vevey/Raven, New York, Vol. 8, pp 272

13. Hurwitz BE, Klaus JR, Llabre MM, Gonzalez A, Lawrence PJ, Maher KJ, Greeson JM, Baum MK, Shor-Posner G, Skyler JS, Schneiderman N (2007) Suppression of human immunodeficiency virus type 1 viral load with selenium supplementation: a randomized controlled trial. Arch Intern Med 167:148-154. https://doi.org/10.1001/archinte.167.2.148

14. Wang C, Lovell RT, Klesius PH (1997) Response to Edwardsiella ictaluri challenge by channel catfish fed organic and inorganic sources of selenium. J Aquat Anim Health 9:172-179. https://doi.org/10.1577/1548-8667(1997) 009\%3c0172:RTEICB\%3e2.3.CO;2

15. Thorarinsson R, Landolt ML, Elliott DG, Pascho RJ, Hardy RW (1994) Effect of dietary vitamin $\mathrm{E}$ and selenium on growth, survival and the prevalence of Renibacterium salmoninarum infection in chinook salmon (Oncorhynchus tshawytscha). Aquaculture 121:343-358. https://doi.org/10.1016/ 0044-8486(94)90269-0

16. Hilton JW, Hodson PV, Slinger SJ (1980) The requirement and toxicity of selenium in rainbow trout (Salmo Gairdneri). J Nutr 110:2527-2535. https://doi.org/10.1093/jn/110.12.2527

17. Hunt AO, Berkoz M, Ozkan F, Yalin S, Ercen Z, Erdogan E, Gunduz SG (2011) Effects of organic selenium on growth, muscle composition, and antioxidant system in rainbow trout. Isr J Aquac - Bamidgeh 63:562

18. Vera T, Isla A, Cuevas A, Figueroa J (2012) Un nuevo medio de cultivo líquido para el patógeno Piscirickettsia salmonis. Arch Med Vet 44:273277. https://doi.org/10.4067/S0301-732X2012000300010

19. Mandakovic D, Glasner B, Maldonado J, Aravena P, González M, Cambiazo V, Pulgar R (2016) Genomic-based restriction enzyme selection for specific detection of Piscirickettsia salmonis by $16 \mathrm{~S}$ rDNA PCR-RFLP. Front Microbiol 7:643. https://doi.org/10.3389/fmicb.2016.00643

20. Strober W (2015) Trypan blue exclusion test of cell viability. Curr Protoc Immunol. https://doi.org/10.1002/0471142735.ima03bs111

21. Paglia DE, Valentine WN (1967) Studies on the quantitative and qualitative characterization of erythrocyte glutathione peroxidase. J Lab Clin Med 70:158-169. https://doi.org/10.5555/uri:pii:0022214367900765

22. Caruffo M, Mandakovic D, Mejías M, Chávez-Báez I, Salgado P, Ortiz D, Montt L, Pérez-Valenzuela J, Vera-Tamargo F, Yánez JM, Wacyk J, Pulgar R (2020) Pharmacological iron-chelation as an assisted nutritional immunity strategy against Piscirickettsia salmonis infection. Vet Res 51:134. https:// doi.org/10.1186/s13567-020-00845-2

23. Zúñiga A, Aravena P, Pulgar R, Travisany D, Ortiz-Severín J, Chávez FP, Maass A, González M, Cambiazo V (2020) Transcriptomic changes of Piscirickettsia salmonis during intracellular growth in a salmon macrophagelike cell line. Front Cell Infect Microbiol 9:426. https://doi.org/10.3389/ fcimb.2019.00426

24. Pacitti D, Lawan MM, Feldmann J, Sweetman J, Wang T, Martin SAM, Secombes CJ (2016) Impact of selenium supplementation on fish antiviral responses: a whole transcriptomic analysis in rainbow trout (Oncorhynchus mykiss) fed supranutritional levels of Sel-Plex ${ }^{\circledR}$. BMC Genomics 17:116. https://doi.org/10.1186/s12864-016-2418-7

25. Council NR (2011) Nutrient requirements of fish and shrimp. National Academies Press

26. Thorarensen $H$, Farrell AP (2011) The biological requirements for postsmolt Atlantic salmon in closed-containment systems. Aquaculture 312:1-14

27. Lee J, Hong S, Sun JH, Moon JK, Boo KH, Lee SM, Lee JW (2019) Toxicity of dietary selenomethionine in juvenile steelhead trout, Oncorhynchus mykiss: tissue burden, growth performance, body composition, hematological parameters, and liver histopathology. Chemosphere 226:755-765. https://doi.org/10.1016/j.chemosphere.2019.03.184

28. Prior RL, Hoang H, Gu L, Wu X, Bacchiocca M, Howard L, Hampsch-Woodill M, Huang D, Ou B, Jacob R (2003) Assays for hydrophilic and lipophilic antioxidant capacity (oxygen radical absorbance capacity $\left(\mathrm{ORAC}_{\mathrm{FL}}\right)$ ) of plasma and other biological and food samples. J Agric Food Chem 51:3273-3279. https://doi.org/10.1021/jf0262256

29. Cao G, Prior RL (1999) Measurement of oxygen radical absorbance capacity in biological samples. Methods Enzymol 299:50-62. https://doi.org/10. 1016/S0076-6879(99)99008-0

30. Sakai DK (1981) Heat inactivation of complement and immune hemolysis reactions in rainbow trout, masu salmon, coho salmon, goldfish and 
tilapia. Bull Japanese Soc Sci Fish 47:565-571. https://doi.org/10.2331/ suisan. 47.565

31. Czyż DM, Potluri LP, Jain-Gupta N, Riley SP, Martinez JJ, Steck TL, Crosson SS, Howard A, Gabay JE (2014) Host-directed antimicrobial drugs with broad-spectrum efficacy against intracellular bacterial pathogens. MBio 5:e01534-e1614. https://doi.org/10.1128/mBio.01534-14

32. Varma DM, Zahid MSH, Bachelder EM, Ainslie KM, Howard A (2020) Formulation of host-targeted therapeutics against bacterial infections. Transl Res 220:98-113

33. Rise ML, von Schalburg KR, Brown GD, Mawer MA, Devlin RH, Kuipers N, Busby M, Beets-Sargent M, Alberto R, Gibbs AR, Hunt P, Shukin R, Zeznik JA, Nelson C, Jones SRM, Smailus DE, Jones SJM, Schein JE, Marra MA, Butterfield YSN, Stott JM, Ng SHS, Davidson WS, Koop BF (2004) Development and application of a salmonid EST database and CDNA microarray: data mining and interspecific hybridization characteristics. Genome Res 14:478-490. https://doi.org/10.1101/gr.1687304

34. Zoidis E, Seremelis I, Kontopoulos N, Danezis GP (2018) Seleniumdependent antioxidant enzymes: Actions and properties of selenoproteins. Antioxidants 7:66

35. Hoffmann PR, Berry MJ (2008) The influence of selenium on immune responses. Mol Nutr Food Res 52:1273-1280. https://doi.org/10.1002/ mnfr.200700330

36. Avery J, Hoffmann PR (2018) Selenium, selenoproteins, and immunity Nutrients 10:1203. https://doi.org/10.3390/nu10091203
37. Dalgaard TS, Briens M, Engberg RM, Lauridsen C (2018) The influence of selenium and selenoproteins on immune responses of poultry and pigs. Anim Feed Sci Technol 238:73-83. https://doi.org/10.1016/j.anifeedsci. 2018.01.020

38. Berntssen M, Sundal TK, Olsvik PA, Amlund H, Rasinger JD, Sele V, Hamre K, Hillestad M, Buttle L, Ørnsrud R (2017) Sensitivity and toxic mode of action of dietary organic and inorganic selenium in Atlantic salmon (Salmo salar). Aquat Toxicol 192:116-126. https://doi.org/10.1016/j.aquat ox.2017.09.014

39. NRC Group (1983) Selenium in Nutrition. National Academies Press, Washington, DC

40. Pahwa R, Jialal I (2019) Chronic Inflammation. StatPearls Publishing, New York

41. Wang L, Zhang X, Wu L, Liu Q, Zhang D, Yin J (2018) Expression of selenoprotein genes in muscle is crucial for the growth of rainbow trout (Oncorhynchus mykiss) fed diets supplemented with selenium yeast. Aquaculture 492:82-90. https://doi.org/10.1016/J.AQUACULTURE.2018.03. 054

\section{Publisher's Note}

Springer Nature remains neutral with regard to jurisdictional claims in published maps and institutional affiliations.
Ready to submit your research? Choose BMC and benefit from:

- fast, convenient online submission

- thorough peer review by experienced researchers in your field

- rapid publication on acceptance

- support for research data, including large and complex data types

- gold Open Access which fosters wider collaboration and increased citations

- maximum visibility for your research: over 100M website views per year

At BMC, research is always in progress.

Learn more biomedcentral.com/submissions 